\title{
CAMBRIDGE
}

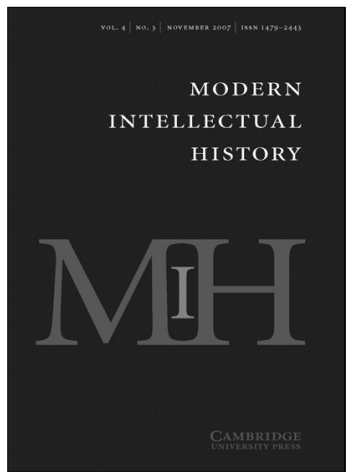

Modern Intellectual History

is available online at

journals.cambridge.org/mih

To subscribe contact

Customer Services

in Cambridge:

Phone $+44(0) 1223326070$

Fax $+44(0) 1223325150$

Email journals@cambridge.org

\section{in New York:}

Phone (845) 3537500

Fax (845) 3534141

Email

subscriptions_newyork@cambridge.org
Modern

Intellectual

History

\section{Editors}

Charles Capper, Boston University, USA

Anthony J. La Vopa, North Carolina State University, USA

Nicholas T. Phillipson, Edinburgh University, UK

This new journal serves as a focal point and forum for scholarship on intellectual and cultural history from 1650 onwards, with primary attention to Europe and the United States but also to transnational developments that encompass the non-West. It enquires into this era's intellectual discourses and texts, their contextual origins and reception, and the recovery of their historical meanings.

Price information is available at journals.cambridge.org/mih

\section{Free email alerts} Keep up-to-date with new material sign up at journals.cambridge.org/register

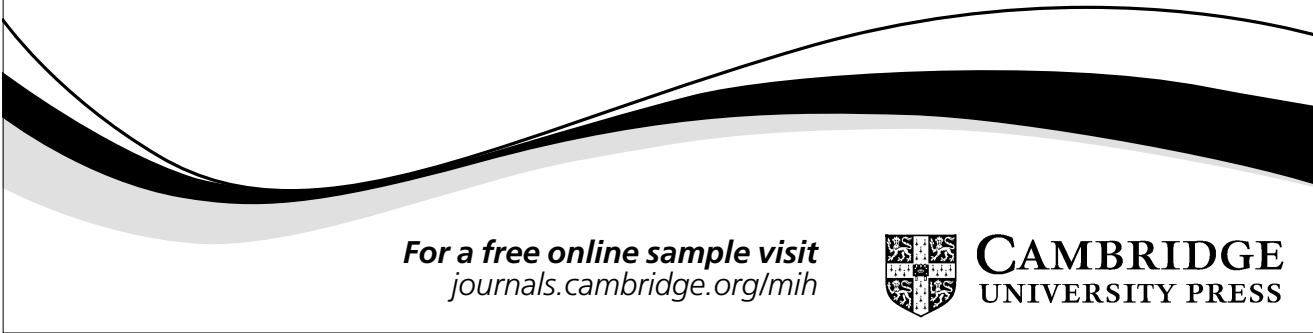




\section{Modern Asian Studies}

Modern Asian Studies promotes original, innovative and rigorous research on the history, sociology, economics and culture of modern Asia. Covering South Asia, South-East Asia, China, Japan and Korea, the journal is published in six parts each year. It welcomes articles which deploy inter-disciplinary and comparative research methods. Modern Asian Studies specialises in the publication of longer monographic essays based on path-breaking new research; it also carries substantial synoptic essays which illuminate the state of the broad field in fresh ways. It contains a book review section which offers detailed analysis of important new publications in the field.

\section{Submissions}

Authors are invited to submit unpublished papers only, and which are not on offer to any other publisher. Copyright of published articles is assigned to Cambridge University Press (with certain rights reserved) on receipt from the author of a signed Copyright Assignment form. Authors are responsible for obtaining permission to reproduce any material in which they do not own copyright, to be used in both print and electronic media, and for ensuring that the appropriate acknowledgements are included in their manuscript.

The Editor welcomes expression of all shades of opinion, but responsibility for them rests with their author. The Editorial Board regrets that it is not able to relay reports for articles not accepted for publication. All correspondence should be addressed to:

\section{Dr Joya Chatterji at modernasianstudies@cambridge.org}

\section{Text and Manuscript Preparation}

All articles (text, notes and references) must be clearly typed in double spacing throughout, including footnotes. Submissions must be submitted as an email attachment in Word. Spelling, dates, references and footnote numbers should be checked for accuracy. The use of diacritical marks, italics and capital letters should be kept to a minimum. References repeated in the footnotes should be by author and short title; or the Harvard system of citation may be used.

The title of the article, the author's name, affiliation, full postal address and corresponding email address, should be typed at the beginning of the article. An abstract of between Ioo and 250 words summarising the contents of the article should be typed before the main text. Sub headings must be used for long articles. Do not use Roman Numerals to divide papers into sections.

Tables should be clearly laid out and numbered consecutively. Vertical lines between columns should be omitted. All figures and totals should be checked for accuracy.

Figures should be supplied as electronic files in either TIFF or EPS format, scanned at a minimum of 320dpi. They should be clearly numbered with an accompanying figure legend. Each figure should be cited at least once in the text. The spelling of place names should be consistent with that used in the text.

When an article has been accepted for publication, the author must submit an electronic copy and should ensure that the final manuscript includes the following:

- Full title

- Author name, affiliation, full postal address and email address

- Abstract of IOO-200 words

- List of references

- Sub section headings

- All figures and tables (with captions and consecutively numbered)

\section{Proofs}

First proofs in PDF format only will be sent to the author who will be expected to return them to the Editor within three days. Authors should note that no substantive alterations or additions can be made to first proofs, and should ensure that their final submissions are thoroughly checked for accuracy.

\section{Offprints}

Each author will receive a PDF file of his or her published article and a copy of the journal issue in which it appears.

\section{GOPYING}

This journal is registered with the Copyright Clearence Center, 27 Congress St, Salem, Mass. or97o. Organizations in the USA who are also registered with C.C.C. may therefore copy material (beyond the limits permitted by sections I07 and Io8 of US copyright law) subject to payment to C.C.C. of the per-copy fee of \$12.00. This consent does not extend to multiple copying for promotional or commercial purposes. Code 0026-749x/o8 \$12.oo. ISI Tear Sheet Service, 350i Market Street, Philadelphia Pennsylvania I9IO4, USA, is authorized to supply single copies of separate papers for private use only. Organizations authorized by the Copyright Licensing Agency may also copy material subject to the usual conditions. For all other use, permission should be sought from Cambridge or the American Branch of Cambridge University Press.

\section{Advertising}

All advertising enquiries from US, Mexico and Canada please contact the Advertising Coordinator (New York) at journals_advertising@cup.org. All enquiries from the Rest of the World please contact Becky Roberts-Advertising Executive (UK) at ad_sales@cambridge.org. 


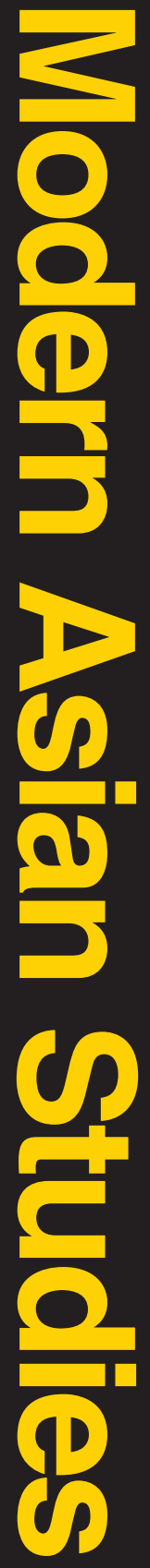

\section{VOLUME 43 PART 1 JANUARY 2009}

\section{CONTENTS}

DAVID GILMARTIN: Introduction

Munis D. FARUQUI: At Empire's End: The Nizam, Hyderabad and Eighteenth-Century India

SUNIL KUMAR: The Ignored Elites: Turks, Mongols and a Persian Secretarial Class in the Early Delhi Sultanate

Stephen F. DALE: 'Silk Road, Cotton Road or ...' Indo-Chinese Trade in Pre-European Times

Claude Markovits: The Political Economy of Opium Smuggling in Early Nineteenth Century India: Leakage or Resistance?

GeORge Bryan SouzA: Opium and the Company: Maritime Trade and Imperial Finances on Java, 1684-1796

MuzAFFAR Alam: The Mughals, the Sufi Shaikhs and the Formation of the Akbari Dispensation VELChERU Narayana RaO AND Sanjay SUBRAHMANYAM: Notes on Political Thought in Medieval and Early Modern South India CYNTHIA TALBOT: Becoming Turk the Rajput Way: Conversion and Identity in an Indian Warrior Narrative

Peter C. Perdue: Nature and Nurture on Imperial China's Frontiers

SuMIT GUHA: The Frontiers of Memory: What the Marathas Remembered of Vijayanagara

RICHARD M. EATON: 'Kiss My Foot,' Said the King: Firearms, Diplomacy, and the Battle for Raichur, 1520

PATRICK MANNING: Frontiers of Family Life: Early Modern Atlantic and Indian Ocean Worlds

CARL A. TrockI: Chinese Revenue Farms and Borders in Southeast Asia

JOHN FOLSOM RICHARDS: Publications 